Article

\title{
Variation in Stripe Rust Resistance and Morphological Traits in Wild Emmer Wheat Populations
}

\author{
Lin Huang ${ }^{1,2, *,+}$, Lihua Feng ${ }^{1,2,+}$, Yu He ${ }^{1}$, Zizhong Tang ${ }^{3}$, Jingshu He ${ }^{1}$, Hanan Sela ${ }^{4}$, \\ Tamar Krugman ${ }^{2}$, Tzion Fahima ${ }^{2}$, Dengcai Liu ${ }^{1}$ (D) and Bihua $\mathrm{Wu}^{1, *}$ \\ 1 Triticeae Research Institute, Sichuan Agricultural University, Wenjiang 611130, Sichuan, China; \\ fenglihua1029@163.com (L.F.); hy2248903541@gmail.com (Y.H.); hejingshu@sicau.edu.cn (J.H.); \\ dcliu7@yahoo.com (D.L.) \\ 2 Institute of Evolution, University of Haifa, 199 Abba-Hushi Avenue, Mt. Carmel, 3498838 Haifa, Israel; \\ krugman@research.haifa.ac.il (T.K.); tfahima@univ.haifa.ac.il (T.F.) \\ 3 College of Life Science, Sichuan Agricultural University, Ya'an 625014, Sichuan, China; 14126@sicau.edu.cn \\ 4 The Institute for Cereal Crops Improvement, Tel Aviv University, P.O. Box 390406139001 Tel Aviv, Israel; \\ hans@post.tau.ac.il \\ * Correspondence: lhuang@sicau.edu.cn (L.H.); wubihua2005@126.com (B.W.); Tel.: +86-28-82650313 (L.H.); \\ +86-28-82650312 (B.W.) \\ + These authors contributed equally to this work.
}

Received: 1 December 2018; Accepted: 17 January 2019; Published: 22 January 2019

\begin{abstract}
Wild emmer wheat (Triticum dicoccoides), the tetraploid progenitor of cultivated wheats, is indigenous to the Near East Fertile Crescent. An important center of distribution is found today in and around the catchment area of the upper Jordan Valley in Israel and surrounding regions. In the current study, the field stripe rust resistance and morphological traits were analyzed using 98 sample accessions that represented the geographical distribution of wild emmer populations in Israel and its vicinity. The resistance tests at two field locations revealed that the majority of the wild emmer accessions possess quantitative resistance against stripe rust. This could be due to the high frequency of $Y r 36$ in the wild emmer populations. The identification of potentially novel stripe rust resistance in this set of germplasm is highly significant. In total, 11 morphological traits were examined in this study. Wide range of natural variation was revealed in the tested morphological traits. Most of the morphological traits had significant correlations with climate variables, indicating that the local environmental conditions have a profound effect on shaping the genetic structure of wild emmer wheat. Our results suggest that wild emmer wheat has the enormous potential to improve stripe rust resistance and various important agronomical traits in wheat.
\end{abstract}

Keywords: morphology; stripe rust resistance; variation; wild emmer wheat; ecogeographical variables

\section{Introduction}

Wild emmer wheat (Triticum turgidum ssp. dicoccoides) is the tetraploid progenitor of domesticated wheat [1]. The geographical distribution of wild emmer habitats extends along the Near East Fertile Crescent, including Israel, Jordan, Syria, Lebanon, eastern Turkey, western Iran, and northern Iraq [2]. An important center of distribution is found in and around the catchment area of the upper Jordan Valley in Israel and surrounding regions. This species thrives across wide ecological amplitude in diverse natural habitats differing from one another in a large number of variables, such as macro and micro-climate, topography, substrate (soil type, bedrock), vegetative community, grazing and 
other disturbances [2,3]. In most of habitats, wild emmer grows in patches of mixed stands with other grasses, such as wild barley and wild oats and a variety of wild legumes [4-6].

Wild emmer has wide genotypic variations in agronomic traits, including grain constituents $[7,8]$, mineral concentration [8,9], abiotic stresses tolerance [10-13], and biotic stresses tolerance [14-18]. Wild emmer is fully compatible with durum wheat; it can be crossed with bread wheat, thereby making its unique gene pool of great importance for wheat improvement.

Stripe rust (Puccinia striiformis f. sp. tritici, Pst) is a devastating fungal disease that attacks much of global wheat production. The rapid emergence of virulent Pst races have overcome most of the known stripe rust resistance genes in wheat. Natural populations of wild emmer possess high genetic diversity of resistance to stripe rust [15,19-22]. Several studies have reported that many wild emmer accessions originating in Israel were highly resistant to $P$ st isolates at seedling and adult stages [15,19,23,24]. Some genotypes showed temperature-dependent resistance usually activated at high temperature [21,22]. To date, six resistance genes, Yr15 [22,23], YrH52 [24], Yr35 [25,26], Yr36 [27,28], YrSM139-1B [29], and YrTZ2 [30], derived from wild emmer have been characterized and mapped. However, only $Y r 15$ and $Y r 36$ have been positionally cloned. $Y r 15$ contains two distinct kinase-like domains arranged in tandem and was designated as WTK1 [31]. Yr36 is a kinase-START gene that confers partial and a broad-spectrum stripe rust resistance against stripe rust at relatively high temperature [27].

Previous studies indicated that natural populations of wild emmer are morphologically diverse. The spike color of wild emmer varies from yellow to black, and the spikelet characters in wild emmer populations were associated with ecogeographic factors [32]. Nevo et al., [33] evaluated ten agronomic traits (including germination, earliness, biomass, and yield variables) and identified genetic variations between and within populations. The inter- and intra-populations variation also observed in heading traits in wild emmer populations from Israel $[34,35]$.

In the current study, we used a new core collection of 98 accessions, representing the geographical distribution of wild emmer populations in Israel and its vicinity to perform a common garden experiment. The objectives were to explore the potential of these wild emmer accessions both as donors of resistance against stripe rust and for agronomically important traits. The association between variations in morphological traits and eco-geographical factors at their site of origin are discussed.

\section{Materials and Methods}

\subsection{Plant Material}

A total of 98 accessions of $T$. dicoccoides collected from 57 collection sites representing a wide range of ecogeographic distribution of $T$. dicoccoides in Israel and its vicinity were used in the current study (Tables S1 and S2). The latitude, longitude, and altitude data of the collection sites were recorded by a GPS (Global Positioning System) receiver. The climatic data were obtained from the BioGIS-Israel biodiversity website (http:/ / www.biogis.huji.ac.il/Map.aspx) and the Israel Meteorological Service (http://ims.gov.il/IMS/CLIMATE).

\subsection{Field Evaluation of Stripe Rust Resistance and Morphological Traits}

A field evaluation for adult-plant stripe rust resistance and morphological traits of $T$. dicoccoides accessions were carried out at the experimental farm of the University of Haifa during the 2013/2014 crop season. The same accessions were evaluated for adult-plant stripe rust resistance at the experimental field of the Triticeae Research Institute, Sichuan Agricultural University, Wenjiang during the $2017 / 2018$ crop season. The temperatures at the experimental field of Haifa varied between a minimum of 8 to $10^{\circ} \mathrm{C}$ to a maximum of 27 to $32^{\circ} \mathrm{C}$ (night/day) during the resistance testing period. The temperatures at the experimental field of Wenjiang varied between a minimum of 11 to $15^{\circ} \mathrm{C}$ to a maximum of 19 to $30^{\circ} \mathrm{C}$ (night/day) during the resistance testing period. Individual plants were spaced $20 \mathrm{~cm}$ apart within a $1.5 \mathrm{~m}$ row, with $30 \mathrm{~cm}$ between rows. Spreader rows of highly susceptible spreader varieties, Local Red or SY95-71, were planted perpendicular and adjacent to the rows of tested 
lines. Seedlings of a susceptible spreader were inoculated around six weeks after planting, with the highly virulent Israeli $P_{s t}$ isolate 5006 that belongs to race 38E134 $[15,36]$ or a mixture of the Chinese prevalent Pst races comprising CYR32, CYR33, CYR34, Zhong4, and HY46 provided by the Research Institute of Plant Protection, Gansu Academy of Agricultural Sciences. Stripe rust infection type (IT) on individual plants was recorded based on a 0-9 scale as described by Line and Qayoum [37]. The ITs were summarized by combining them into four classes of which $0-1$ were considered as resistant reactions (R), 2-4 as quantitative resistance (QR), 5-6 as intermediate (MR), and 7-9 as susceptible reactions (S) (Figure S1). Disease notes were taken when the susceptibility of flag leaves of the spreader varieties was fully expressed.

The following morphological traits were measured in the first culm and spike of each plant: spike length (SL), spikelet length (SpL), top awn length (TAL), empty glume width (GW) (Figure 1), number of spikelets per spike (NSp), heading date (HD) was recorded at the date when the first spike of a plant had fully exposed (basal spikelet passed the ligule of the flag leaf), culm length (CL) was measured at maturity from the soil surface to the base of spike, flag leaf length (FL), flag leaf width (FW) was recorded at the widest part of the flag leaf. In addition, tiller number (TN) and an average weight of 50 seeds (SW) were recorded. For each accession, the mean measurement of at least three plants was calculated for each trait.

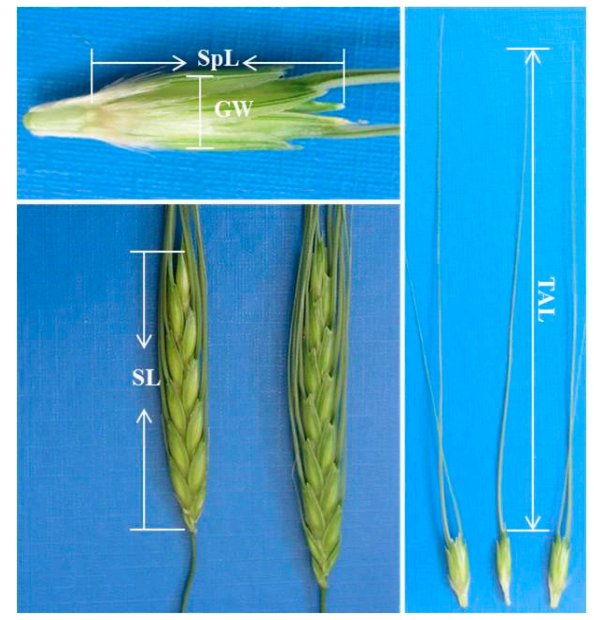

Figure 1. Morphology of T. dicoccoides spike. Measured positions are shown for SpL, GW, SL, and TAL.

\subsection{Analysis of Presence/Absence Polymorphism in Yr15 and Yr36}

Genomic DNA was extracted from leaves using the CTAB protocol [38]. Presence/absence of $Y r 15$ and $Y_{r} 36$ was analyzed using PCR amplification with the gene-specific primers of $Y r 15$ and $Y r 36$ (Table S3). PCR reactions were performed using the Gene Amp PCR system 9700 (Applied Biosystems, Foster City, CA, USA) in $15 \mu \mathrm{L}$ reaction volume containing $50 \mathrm{ng}$ of genomic DNA, $1 \times$ PCR buffer, $300 \mathrm{nM}$ of each primer, $200 \mu \mathrm{M}$ of each dNTP and 0.5 U of Dream Taq ${ }^{\mathrm{TM}}$ DNA Ploymerase (Thermo Scientific, Waltham, MA, USA). PCR products were resolved on $1.5 \%$ agarose gel and visualized by GelRed (Biotium, Hayward, CA, USA) staining.

\subsection{Statistical Analysis}

Statistical analyses were conducted using SPSS 16.0 Software (SPSS Inc., Chicago, IL, USA). Correlation analyses were used to assess the association between morphological traits and ecogeographical variables of collection sites. Cluster analysis among the traits was conducted using clustering program (http://genomes.urv.es/UPGMA/). This program calculates Pearson correlation coefficients between pairs of sets of variables, transformed coefficients into distances and made a clustering using the unweighted pair group method with arithmetic mean (UPGMA) algorithm [39]. 


\section{Results}

\subsection{Variation in Stripe Rust Resistance}

The 98 accessions of $T$. dicoccoides were evaluated in adult-plant stage against stripe rust at two environmentally diverse field locations. Of the 98 accessions, 74 (76\%) accessions were resistant, and two (2\%) were intermediate at Haifa field, and $51(52 \%)$ accessions were resistant, and $15(10 \%)$ were intermediate at Wenjiang field. Data from both field locations revealed that the majority of the resistant accessions showed partial resistance (QR) response (Figure S1; IT 2-4; in a 0-9 scale) [37]. Few wild emmer accessions were identified as highly resistant to stripe rust at two locations. However, some different responses were observed between the two locations. For example, fifteen accessions showed partial resistance at Haifa and intermediate at Wenjiang location. Two accessions were intermediate at Haifa and susceptible at Wenjiang (Table S1).

In the $98 \mathrm{~T}$. dicoccoides accessions screened, 12 (12.24\%) and 65 (66.33\%) accessions were positive for $Y r 15$ and $Y r 36$, respectively. Seventy (71.43\%) accessions had either $Y r 15$ or $Y r 36$. Seven accessions $(7.14 \%)$ had both $Y r$ genes. The accessions carrying either $Y r 15$ or both $Y r 15$ and $Y_{r} 36$ showed highly resistance (IT 0-1), while most accessions with Yr36 alone exhibited partial resistance (IT 2-4) to stripe rust. Three accessions (DIC113, DIC641, and DIC767) carrying Yr36 alone were highly resistant (IT 0-1) at both field sites. Notably, the partial resistance response was observed in four accessions (DIC6, DIC13, DIC283, and DIC809) without both Yr15 and Yr36 (Table S1).

\subsection{Variation in Morphological Traits}

The common garden experiment revealed variation in all tested traits among T. dicoccoides populations (Table 1). Except HD, SpL, and SL, we found in all traits wide variation that was exhibited by a large difference between the minimum and maximum values. For example, the maximum and minimum differences reach to 3-fold and 5-fold for the average weight of SW and TN, respectively. The HD ranged from 129.33 to 157.67 days $(\mathrm{d})$ (median $=144.33 \mathrm{~d}$ ), and $73.47 \%$ of the accessions were in the range of 140 to $150 \mathrm{~d}$. The SpL varied from 13.52 to $20.33 \mathrm{~mm}$ (median = $16.67 \mathrm{~mm}$ ), of which $86.73 \%$ of the samples were in the range 15.00 to $18.00 \mathrm{~mm}$. The SL ranged from 7.10 to $12.47 \mathrm{~cm}$ (median $=9.00$ ), and $67.35 \%$ of the accessions were in the range of 8.00 to $10.00 \mathrm{~cm}$. Distribution of traits across populations showed that while few $T$. dicoccoides accessions had maximum values of TN and NSp, most accessions with minimum values of CL, TAL, SpL, and GW were originated in the southern population of Israel.

Table 1. Variation in 11 morphological traits in T. dicocciodes accessions.

\begin{tabular}{|c|c|c|c|c|c|c|c|}
\hline Trait & & & Average & STDV & Min. & Median & Max. \\
\hline HD & Heading date & (day) & 144.40 & 5.32 & 129.33 & 144.33 & 157.67 \\
\hline $\mathrm{CL}$ & Culm length & $(\mathrm{cm})$ & 100.95 & 14.69 & 53.65 & 101.70 & 128.57 \\
\hline SL & Spike length & $(\mathrm{cm})$ & 9.07 & 1.01 & 7.10 & 9.00 & 12.47 \\
\hline TAL & Top awn length & $(\mathrm{cm})$ & 14.71 & 2.21 & 8.20 & 14.43 & 19.30 \\
\hline FL & Flag leaf length & $(\mathrm{cm})$ & 18.68 & 3.68 & 9.85 & 18.30 & 28.10 \\
\hline FW & Flag leaf width & $(\mathrm{cm})$ & 1.19 & 0.21 & 0.65 & 1.17 & 1.77 \\
\hline SpL & Spikelet length & $(\mathrm{mm})$ & 16.72 & 1.25 & 13.52 & 16.67 & 20.33 \\
\hline GW & Empty glume width & $(\mathrm{mm})$ & 5.13 & 0.66 & 3.43 & 5.00 & 7.15 \\
\hline TN & Tiller number & & 18.81 & 7.00 & 9.00 & 17.33 & 47.67 \\
\hline NSp & Number of spikelets per spike & & 30.38 & 4.66 & 21.00 & 30.00 & 46.33 \\
\hline SW & Fifty seeds weight & (g) & 1.33 & 0.38 & 0.67 & 1.34 & 2.24 \\
\hline
\end{tabular}

Cluster analysis of the morphological traits showed strong associations between traits; the highest correlations were found among the NSp, SL, GW, and FW traits (Figure 2a), and among the spike and spikelet traits (Figure 2b). Furthermore, TN was associated with spike length (SL) and number of spikelets per spike (NSp). SL was highly correlated with NSp. In addition, SpL and TAL were 
clustered in one group. CL was associated with SW. Notably, GW was well correlated with FW but was separated from the spike and spikelet traits. HD was nearly independent of other traits (Figure 2b).
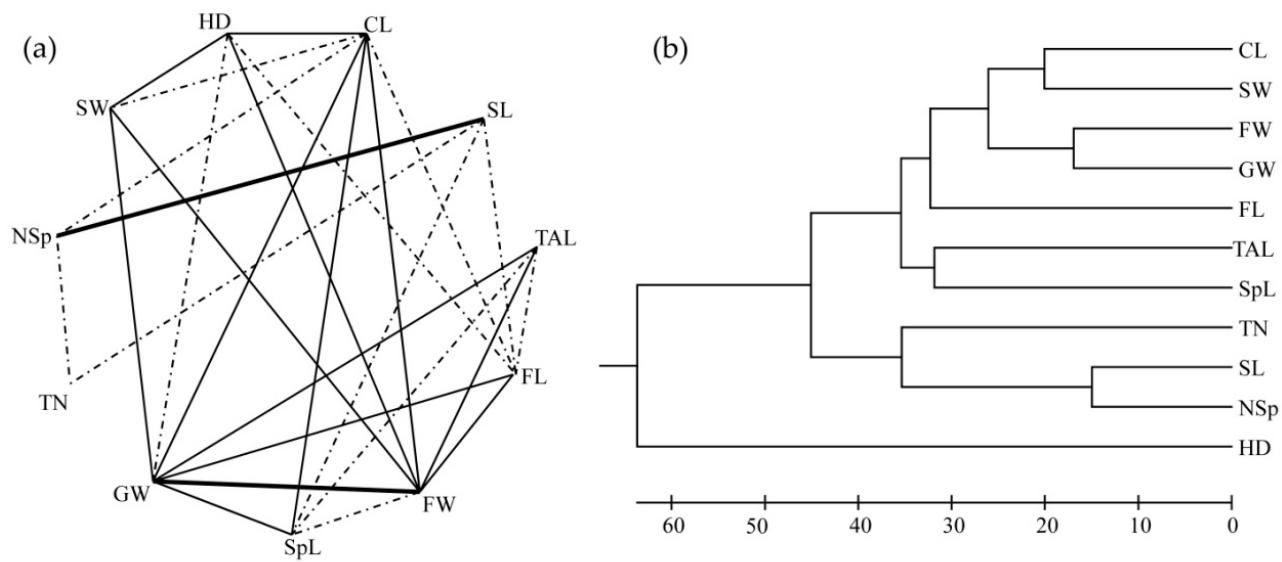

$$
\begin{array}{ll}
- & \mathrm{r}^{2}>0.36, \mathrm{P}<0.01 \\
-\cdots & 0.16<\mathrm{r}^{2}<0.36, \mathrm{P}<0.01 \\
-\cdot-0.04<\mathrm{r}^{2}<0.16, \mathrm{P}<0.01
\end{array}
$$

Figure 2. Relationship of the 11 morphological traits. (a) The relation based on the Pearson coefficient values. Higher values are connected with thicker lines. (b) A dendrogram constructed by the UPGMA method based on the Pearson coefficients. The Pearson values (r) were transformed to the distance values $(\mathrm{d})$ as follows: $\mathrm{d}=(1-\mathrm{r})^{*} 100$.

\subsection{Associations between Morphological Traits and Ecogeographical Variables}

Correlation analysis between morphological traits and ecogeographical variables resulted in numerous significant coefficients ranging from 0.199 to 0.587 (Table 2). Morphological traits of CL, FL, FW, GW, and SW were significant $(p<0.05)$ correlated with temperature variables, resulting in fourteen positive coefficients ranging between 0.209 and 0.507 . Pronounced associations were also obtained with Lat, Lon, Alt, and Rn with twelve significant $(p<0.05)$ coefficients, ranging between 0.231 and 0.587 (Table 2). Furthermore, the values of CL, FW, GW, and SW were highly positive $(p<0.01)$ correlated with Lat and Lon. In addition, TN $(\mathrm{r}=0.268 p<0.01)$ and $\mathrm{HD}(\mathrm{r}=0.341, p<0.01)$ were correlated positively with $\mathrm{Rn}$. These two morphological traits were negatively correlated with temperature variables (HD was correlated with Tjmin, Tjmax, and Tsr; TN was correlated with Tj).

Table 2. Coefficients of correlation (r) between morphological traits of $T$. dicocciodes and the ecogeographical variables at their sites of collection.

\begin{tabular}{lllllllll}
\hline & Lat & Lon & Alt & Rn & Tjmin & Tsr & Tj & Tjmax \\
\hline HD & -0.088 & $-0.353^{* *}$ & $0.219^{*}$ & $0.341^{* *}$ & $-0.250^{*}$ & $-0.439^{* *}$ & -0.109 & $-0.447^{* *}$ \\
CL & $0.463^{* *}$ & $0.524^{* *}$ & -0.147 & 0.184 & -0.016 & $0.398^{* *}$ & -0.086 & 0.096 \\
SL & 0.002 & 0.004 & 0.196 & -0.005 & -0.164 & -0.021 & -0.158 & -0.132 \\
TAL & $0.203^{*}$ & 0.058 & -0.079 & 0.007 & 0.071 & -0.066 & 0.108 & 0.022 \\
FL & -0.071 & 0.110 & $-0.199^{*}$ & $-0.231^{*}$ & $0.227^{*}$ & $0.209^{*}$ & 0.121 & $0.282^{* *}$ \\
FW & $0.276^{* *}$ & $0.350^{* *}$ & $-0.336^{* *}$ & -0.101 & $0.307^{* *}$ & $0.314^{* *}$ & $0.229^{*}$ & $0.410^{* *}$ \\
SpL & $0.210^{*}$ & 0.143 & $-0.108^{*}$ & -0.084 & 0.139 & 0.038 & 0.149 & 0.133 \\
GW & $0.346^{* *}$ & $0.359^{* *}$ & $-0.446^{* *}$ & -0.166 & $0.400^{* *}$ & $0.270^{* *}$ & $0.300^{* *}$ & $0.413^{* *}$ \\
TN & 0.084 & 0.083 & $0.136^{*}$ & $0.268^{* *}$ & -0.183 & 0.075 & $-0.232^{*}$ & -0.139 \\
NSp & -0.152 & 0.007 & $0.357^{* *}$ & 0.053 & $-0.322^{* *}$ & 0.091 & $-0.376^{* *}$ & $-0.257^{*}$ \\
SW & $0.440^{* *}$ & $0.587^{* *}$ & -0.189 & -0.026 & 0.084 & $0.507^{* *}$ & -0.026 & $0.265^{* *}$ \\
\hline
\end{tabular}

Lat latitude, Lon longitude, Alt altitude, Rn mean annual rainfall, Tjmin minimal January temperature, Tsr seasonal temperature range, Tj mean January temperature, Tjmax maximal June temperature, ${ }^{*}$ and ${ }^{* *}$ indicate significant effects at $p<0.05$, and 0.01 , respectively. 


\section{Discussion}

The disease responses at the adult-plant stage tested under two field conditions revealed enormous potential of wild emmer for resistance against the stripe rust pathogen. The results demonstrate the large variation of ITs in wild emmer accessions. Moreover, different resistance patterns were observed in few accessions. These could be due to the different virulence profile of stripe rust isolates at two sites. For example, the Israeli Pst race 38E134 was avirulent to $Y r 1, Y r 3, Y r 4, Y r 8, Y r 9, Y r 10, Y r C V$, and $Y r S P[15,36]$, whereas the Chinese $P$ st races used in this study, such as CYR32, was virulent to $Y r 1, Y r 3$, $Y r 4, Y r 9, Y r C V$, and $Y r S P$ [40], and the CYR34 was virulent to $Y_{r 1}, Y r 8, Y r 9, Y r 10, Y r S P$, and $Y_{r} 26$ [41].

In the present study, we found a low percentage (12.24\%) of the wild emmer accessions from Israel were $Y r 15$ positive, and a high percentage $(66.33 \%)$ of accessions were $Y r 36$ positive. Field testing showed that three accessions with $Y r 36$ alone had highly resistance response (IT 0-1), whereas four accessions without both $Y_{r} 15$ and $Y_{r} 36$ had partial resistance response (IT 2-4). These findings suggest that other effective major or partial resistance genes are presented in the wild emmer populations [18]. Further studies are needed to identify resistance genes in current resistant accessions and develop molecular markers for the genes to efficiently use of these resistance sources for wheat breeding.

Israel and surrounding regions are an important center of diversity and distribution of wild emmer wheat [2]. This small geographical area was quite diverse with respect to naturally occurring ecological conditions [42]. In the present study, the 98 newly collected wild emmer accessions from 57 sites were used to evaluate the morphological traits. As expected from these diverse habits, wide natural variations of the tested morphological traits were observed in the wild emmer accessions. These results are in agreement with a previous study that the natural populations of wild emmer in these regions were largely varied in quantitative traits of agronomic importance [33].

We found remarkable differences in morphological traits in T. dicoccoides populations. Traits, such as early heading date, high yield and yield-relevant traits (SW, SL, SpL, and NsP), productive tiller number, and lower culm length are of agronomical importance. Some morphological traits were highly correlated with each other (SL was correlated with NSp; FW was correlated with GW), indicating that the same genes or a small number of major genes may control these traits. Several quantitative trait loci (QTLs) associated with morpho-physiological traits were reported in recombinant inbred lines between durum wheat (Langdon) and wild emmer (G18-16), under contrasting water availabilities [11]. Detection of the QTLs and major genes that control the examined traits in the present study are required to further understand the genetic framework for morphological diversification in the T. dicoccoides populations.

Environmental stress is a major driving force of the evolution of living organisms [43,44]. The eastern Mediterranean region is characterized by a long, hot, dry summer and a short, mild, wet winter with fluctuating amounts and distribution of precipitation. The T. dicoccoides from this region has accumulated high genetic diversity for biotic and abiotic stress adaptations. The significant correlations between genetic diversity of $T$. dicoccoides populations and ecogeographical parameters have been reported by several previous studies [10,45-47]. In this study, most of the examined morphological traits showed significant correlation with climate variables. For example, the HD was largely influenced by the climate variables, such as rainfall and temperature. Early heading types were predominant in the warmer and drier habitats, mainly in the central and southern areas of Israel. Early heading enables wild emmer in warmer and aridity areas to avoid the heat and aridity stresses in the early summer [35]. In addition, latitudinal and longitudinal geographic clines found for CL, FL, GW, and SW diversification deserve a note. Our results indicated that the values of $\mathrm{CL}, \mathrm{FL}, \mathrm{GW}$, and SW traits tend to be increased in the northeastern region of Israel. These areas with mild environmental conditions may enable plants to achieve higher biomass production. Taken together, our results indicate that the morphological diversification of T. dicoccoides was established as the result of adaptation to diversified habitats. Determination of the major genes controlling such morphological variations may help to understand the genetic mechanisms that underlie the adaptation to local environment conditions of 
the T. dicoccoides habitats and to further utilize the excellent morphological traits in T. dicoccoides for wheat breeding.

\section{Conclusions}

The expanding global human population poses huge challenges to world agriculture. Developing wheat cultivars with excellent resistance and economic important agronomic traits is the most effective approach to increase the grain yield. The wide ecological amplitude of wild emmer wheat in the Fertile Crescent and its unique genetic structure makes its gene pool of great importance for wheat breeding. In the current study, the common garden experiment revealed a high percentage of partial resistance against stripe rust and wide variation of morphological traits in wild emmer populations. These results suggest that our new collection has the potential to improve agronomical traits and stripe rust resistance in wheat. The accessions especially from the north region of Israel with profound agronomical traits (e.g., GW and SW) are more important genetic resources and have a significant potential for wheat improvement.

Supplementary Materials: The following are available online at http:/ /www.mdpi.com/2073-4395/9/2/44/ s1, Figure S1: Stripe rust resistance phenotype in T. dicoccoides accessions, Table S1: The presence/absence polymorphism of Yr15 and Yr36 genes and the reaction to stripe rust in populations of T. dicocciodes, Table S2: The geographical and climatological data for 57 collection sites, Table S3: Oligonucleotide primers used for screening of Yr15 and Yr36 genes in T. dicocciodes populations.

Author Contributions: Conceptualization, T.F. and L.H.; Methodology, L.H. and L.F.; Software, L.H. and L.F.; Validation, L.H. and L.F.; Formal analysis, L.H. and L.F.; Investigation, L.H., L.F., Z.T., J.H. and Y.H.; Resources, H.S., L.H., T.K. and T.F.; Writing-Original Draft Preparation, L.H. and L.F.; Writing-Review and Editing, D.L., B.W. and T.K.; Supervision, T.F. and D.L.; Funding Acquisition, L.H. and B.W.

Acknowledgments: This work was financially supported by grants from the National Natural Science Foundation of China (no. 31801360; no. 31671689; no. 31571668), the Education Department of Sichuan Province (no. 18ZA0392).

Conflicts of Interest: The authors have declared no conflict of interest.

\section{References}

1. McFadden, E.; Sears, E. The origin of Triticum spelta and its free-threshing hexaploid relatives. J. Hered. 1946, 37, 107-116. [CrossRef]

2. Harlan, J.R.; Zohary, D. Distribution of wild wheats and barley. Science 1966, 153, 1074-1080. [CrossRef] [PubMed]

3. Zohary, D.; Hopf, M. Domestication of plants in the old world. J. Appl. Ecol. 1993, 130, 365-372.

4. Oppenheimer, H.R. Ecological relationship of wild emmer in Israel and A. Aaronsohn's contribution to the theory of the origin of cultivated wheat. Genet. Agrar. 1963, 17, 249-258.

5. Feldman, M.; Sears, E.R. The wild gene resources of wheat. Sci. Am. 1981, 244, 102-112. [CrossRef]

6. Ozkan, H.; Willcox, G.; Graner, A.; Salamini, F.; Kilian, B. Geographic distribution and domestication of wild emmer wheat (Triticum dicoccoides). Genet. Resour. Crop Evol. 2011, 58, 11-53. [CrossRef]

7. Uauy, C.; Brevis, J.C.; Dubcovsky, J. The high grain protein content gene Gpc-B1 accelerates senescence and has pleiotropic effects on protein content in wheat. J. Exp. Bot. 2006, 57, 2785-2794. [CrossRef] [PubMed]

8. Peleg, Z.; Saranga, Y.; Yazici, A.; Fahima, T.; Ozturk, L.; Cakmak, I. Grain zinc, iron and protein concentrations and zinc-efficiency in wild emmer wheat under contrasting irrigation regimes. Plant Soil 2008, 306, 57-67. [CrossRef]

9. Bonfil, D.J.; Kafkafi, U. Wild wheat adaptation in different soil ecosystems as expressed in the mineral concentration of the seeds. Euphytica 2000, 114, 123-134. [CrossRef]

10. Peleg, Z.; Fahima, T.; Abbo, S.; Krugman, T.; Nevo, E.; Yakir, D.; Saranga, Y. Genetic diversity for drought resistance in wild emmer wheat and its ecogeographical associations. Plant Cell Environ. 2005, 28, 176-191. [CrossRef]

11. Peleg, Z.; Fahima, T.; Krugman, T.; Abbo, S.; Yakir, D.; Korol, A.B.; Saranga, Y. Genomic dissection of drought resistance in durum wheat $\mathrm{x}$ wild emmer wheat recombinant inbreed line population. Plant Cell Environ. 2009, 32, 758-779. [CrossRef] [PubMed] 
12. Krugman, T.; Chague, V.; Peleg, Z.; Balzergue, S.; Just, J.; Korol, A.B.; Nevo, E.; Saranga, Y.; Chalhoub, B.; Fahima, T. Multilevel regulation and signalling processes associated with adaptation to terminal drought in wild emmer wheat. Funct. Integr. Genom. 2010, 10, 167-186. [CrossRef] [PubMed]

13. Krugman, T.; Peleg, Z.; Quansah, L.; Chague, V.; Korol, A.B.; Nevo, E.; Saranga, Y.; Fait, A.; Chalhoub, B.; Fahima, T. Alteration in expression of hormone-related genes in wild emmer wheat roots associated with drought adaptation mechanisms. Funct. Integr. Genom. 2011, 11, 565-583. [CrossRef] [PubMed]

14. Ben-David, R.; Xie, W.L.; Peleg, Z.; Saranga, Y.; Dinoor, A.; Fahima, T. Identification and mapping of PmG16, a powdery mildew resistance gene derived from wild emmer wheat. Theor. Appl. Genet. 2010, 121, 499-510. [CrossRef] [PubMed]

15. Cheng, J.; Yan, J.; Sela, H.; Manisterski, J.; Lewinsohn, D.; Nevo, E.; Fahima, T. Pathogen race determines the type of resistance response in the stripe rust-Triticum dicoccoides pathosystem. Physiol. Plant. 2010, 139, 269-279. [PubMed]

16. Anikster, Y.; Manisterski, J.; Long, D.L.; Leonard, K.J. Leaf rust and stem rust resistance in Triticum dicoccoides populations in Israel. Plant Dis. 2005, 89, 55-62. [CrossRef]

17. Buerstmayr, M.; Alimari, A.; Steiner, B.; Buerstmayr, H. Genetic mapping of QTL for resistance to fusarium head blight spread (type 2 resistance) in a Triticum dicoccoides $x$ Triticum durum backcross-derived population. Theor. Appl. Genet. 2013, 126, 2825-2834. [CrossRef] [PubMed]

18. Huang, L.; Raats, D.; Sela, H.; Klymiuk, V.; Lidzbarsky, G.; Feng, LH.; Krugman, T.; Fahima, T. Evolution and adaptation of wild emmer wheat populations to biotic and abiotic stresses. Annu. Rev. Phytopathol. 2016, 54, 279-301. [CrossRef] [PubMed]

19. Sela, H.; Ezrati, S.; Ben-Yehuda, P.; Manisterski, J.; Akhunov, E.; Dvorak, J.; Breiman, A.; Korol, A. Linkage disequilibrium and association analysis of stripe rust resistance in wild emmer wheat (Triticum turgidum ssp. dicoccoides) population in Israel. Theor. Appl. Genet. 2014, 127, 2453-2463. [CrossRef] [PubMed]

20. The, T.T.; Nevo, E.; McIntosh, R.A. Responses of Israeli wild emmers to selected Australian pathotypes of Puccinia species. Euphytica 1993, 71, 75-81. [CrossRef]

21. Van Silfhout, C.H. Identification and Characterization of Resistance to Yellow Rust and Powdery Mildew in Wild Emmer Wheat and Their Transfer to Bread Wheat. Ph.D. Thesis, Wageningen University, Wageningen, The Netherland, 23 November 1989.

22. Gerechter-Amitai, Z.K.; van Silfhout, C.H. Race-specificity of temperature-sensitive genes for resistance to Puccinia striiformis in Triticum dicoccoides. Euphytica 1989, 43, 7-14. [CrossRef]

23. Yaniv, E.; Raats, D.; Ronin, Y.; Korol, A.B.; Grama, A.; Bariana, H.; Dubcovsky, J.; Schulman, A.H.; Fahima, T. Evaluation of marker-assisted selection for the stripe rust resistance gene $Y r 15$, introgressed from wild emmer wheat. Mol. Breed. 2015, 35, 43. [CrossRef] [PubMed]

24. Peng, J.H.; Fahima, T.; Roder, M.S.; Li, Y.C.; Dahan, A.; Grama, A.; Ronin, Y.I.; Korol, A.B.; Nevo, E. Microsatellite tagging of the stripe-rust resistance gene $Y r H 52$ derived from wild emmer wheat, Triticum dicoccoides, and suggestive negative crossover interference on chromosome 1B. Theor. Appl. Genet. 1999, 98, 862-872. [CrossRef]

25. Marais, G.F.; Pretorius, Z.A.; Wellings, C.R.; McCallum, B.; Marais, A.S. Leaf rust and stripe rust resistance genes transferred to common wheat from Triticum dicoccoides. Euphytica 2005, 143, 115-123. [CrossRef]

26. Dadkhodaie, N.A.; Karaoglou, H.; Wellings, C.R.; Park, R.F. Mapping genes Lr53 and Yr35 on the short arm of chromosome $6 \mathrm{~B}$ of common wheat with microsatellite markers and studies of their association with Lr36. Theor. Appl. Genet. 2011, 122, 479-487. [CrossRef] [PubMed]

27. Fu, D.L.; Uauy, C.; Distelfeld, A.; Blechl, A.; Epstein, L.; Chen, X.M.; Sela, H.; Fahima, T.; Dubcovsky, J. A kinase-START gene confers temperature-dependent resistance to wheat stripe rust. Science 2009, 323, 1357-1360. [CrossRef]

28. Uauy, C.; Brevis, J.C.; Chen, X.M.; Khan, I.; Jackson, L.; Chicaiza, O.; Distelfeld, A.; Fahima, T.; Dubcovsky, J. High-temperature adult-plant (HTAP) stripe rust resistance gene $Y r 36$ from Triticum turgidum ssp. dicoccoides is closely linked to the grain protein content locus Gpc-B1. Theor. Appl. Genet. 2005, 112, 97-105. [CrossRef]

29. Zhang, H.; Zhang, L.; Wang, C.Y.; Wang, Y.J.; Zhou, X.L.; Lv, S.K.; Liu, X.L.; Kang, Z.S.; Ji, W.Q. Molecular mapping and marker development for the Triticum dicoccoides-derived stripe rust resistance gene YrSM139-1B in bread wheat cv. Shaanmai 139. Theor. Appl. Genet. 2016, 129, 369-376. [CrossRef] 
30. Wang, Z.Z.; Xie, J.Z.; Guo, L.; Zhang, D.Y.; Li, G.Q.; Fang, T.L.; Chen, Y.X.; Li, J.; Wu, Q.H.; Lu, P.; et al. Molecular mapping of $Y r T Z 2$, a stripe rust resistance gene in wild emmer accession TZ-2 and its comparative analyses with Aegilops tauschii. J. Integr. Agr. 2018, 17, 1267-1275. [CrossRef]

31. Klymiuk, V.; Yaniv, E.; Huang, L.; Raats, D.; Fatiukha, A.; Chen, S.; Feng, L.; Frenkel, Z.; Krugman, T.; Lidzbarsky, G.; et al. Cloning of the wheat Yr15 resistance gene sheds light on the plant tandem kinase-pseudokinase family. Nat. Commun. 2018, 9, 3735. [CrossRef]

32. Nevo, E.; Golenberg, E.; Beiles, A.; Brown, A.H.D.; Zohary, D. Genetic diversity and environmental associations of wild wheat, Triticum dicoccoides, in Israel. Theor. Appl. Genet. 1982, 62, 241-254. [CrossRef] [PubMed]

33. Nevo, E.; Beiles, A.; Gutterman, Y.; Storch, N.; Kaplan, D. Genetic-resources of wild cereals in Israel and Vicinity. 1. Phenotypic variation within and between populations of wild wheat, Triticum dicoccoides. Euphytica 1984, 33, 717-735. [CrossRef]

34. Kato, K.; Mori, Y.; Beiles, A.; Nevo, E. Geographical variation in heading traits in wild emmer wheat, Triticum dicoccoides. 1. Variation in vernalization response and ecological differentiation. Theor. Appl. Genet. 1997, 95, 546-552. [CrossRef]

35. Kato, K.; Tanizoe, C.; Beiles, A.; Nevo, E. Geographical variation in heading traits in wild emmer wheat, Triticum dicoccoides. II. Variation in heading date and adaptation to diverse eco-geographical conditions. Hereditas 1998, 128, 33-39. [CrossRef]

36. Huang, L.; Sela, H.; Feng, L.; Chen, Q.; Krugman, T.; Yan, J.; Dubcovsky, J.; Fahima, T. Distribution and haplotype diversity of WKS resistance genes in wild emmer wheat natural populations. Theor. Appl. Genet. 2016, 129, 921-934. [CrossRef]

37. Line, R.F.; Qayoum, A. Virulence, Aggressiveness, Evolution, and Distribution of Races of Puccinia striiformis (the Causes of Stripe Rust of Wheat) in North America, 1968-1987; Technical Bulletin 1788; United State Department of Agriculture: Washington, DC, USA, 1992.

38. Rogers, S.O.; Bendich, A.J. Extraction of DNA from milligram amounts of fresh, herbarium and mummified plant tissues. Plant Mol. Biol. 1985, 5, 69-76. [CrossRef]

39. Garcia-Vallve, S.; Palau, J.; Romeu, A. Horizontal gene transfer in glycosyl hydrolases inferred from codon usage in Escherichia coli and Bacillus subtilis. Mol. Biol. Evol. 1999, 16, 1125-1134. [CrossRef]

40. Wan, A.M.; Zhao, Z.H.; Chen, X.M.; He, Z.H.; Jin, S.L.; Jia, Q.Z.; Yao, G.; Yang, J.X.; Wang, B.T.; Li, G.B.; et al. Wheat stripe rust epidemic and virulence of Puccinia striiformis f. sp. tritici in China in 2002. Plant Dis. 2004, 88, 896-904. [CrossRef]

41. Han, D.J.; Wang, Q.L.; Chen, X.M.; Zeng, Q.D.; Wu, J.H.; Xue, W.B.; Zhan, G.M.; Huang, L.L.; Kang, Z.S. Emerging Yr26-virulent races of Puccinia striiformis $\mathrm{f}$. tritici are threatening wheat production in the Sichuan basin, China. Plant Dis. 2015, 99, 754-760.

42. Nevo, E. Molecular evolution and ecological stress at global, regional and local scales: The Israeli perspective. J. Exp. Zool. 1998, 282, 95-119. [CrossRef]

43. Hoffman, A.A.; Parsons, P.A. Evolutionary Genetics and Environmental Stress; Oxford University Press: Oxford, UK, 1991.

44. Parsons, P.A. Environments and evolution: Interactions between stress, resource inadequacy and energetic efficiency. Biol. Rev. 2005, 80, 589-610. [CrossRef] [PubMed]

45. Fahima, T.; Roder, M.S.; Wendehake, K.; Kirzhner, V.M.; Nevo, E. Microsatellite polymorphism in natural populations of wild emmer wheat, Triticum dicoccoides, in Israel. Theor. Appl. Genet. 2002, 104, 17-29. [CrossRef] [PubMed]

46. Fahima, T.; Sun, G.L.; Beharav, A.; Krugman, T.; Beiles, A.; Nevo, E. RAPD polymorphism of wild emmer wheat populations, Triticum dicoccoides, in Israel. Theor. Appl. Genet. 1999, 98, 434-447. [CrossRef]

47. Li, Y.C.; Fahima, T.; Korol, A.B.; Peng, J.H.; Roder, M.S.; Kirzhner, V.; Beiles, A.; Nevo, E. Microsatellite diversity correlated with ecological-edaphic and genetic factors in three microsites of wild emmer wheat in North Israel. Mol. Biol. Evol. 2000, 17, 851-862. [CrossRef]

(C) 2019 by the authors. Licensee MDPI, Basel, Switzerland. This article is an open access article distributed under the terms and conditions of the Creative Commons Attribution (CC BY) license (http:/ / creativecommons.org/licenses/by/4.0/). 